\title{
The role of interleukin-1beta and other potential genetic markers as indicators of gastric cancer risk
}

\author{
Esther Troost $\mathrm{MD}^{1}$, Georgina L Hold PhD ${ }^{1}$, Malcolm G Smith MD ${ }^{1}$, Wong-Ho Chow PhD², \\ Charles S Rabkin MD², Kenneth EL McColl MD², Emad M El-Omar MD ${ }^{1}$
}

E Troost, GL Hold, MG Smith, WH Chow, CS Rabkin, KEL McColl, EM El-Omar. The role of interleukin-1beta and other potential genetic markers as indicators of gastric cancer risk. Can J Gastroenterol 2003;17(Suppl B):8B-12B.

Helicobacter pylori infects half of the world's population, and is associated with asymptomatic gastritis and also with more serious conditions such as peptic ulcer disease and gastric carcinoma. The clinical outcome is largely dependent on the severity and distribution of the $\mathrm{H}$ pylori-induced gastritis, but the pathogenesis remains poorly understood. Bacterial virulence factors and environmental influences contribute to the pathogenesis, but do not explain the divergent outcomes. There is emerging evidence that host genetic factors play a key role in determining the clinical outcome of $H$ pylori infection. In particular, proinflammatory genotypes of the interleukin-1 beta (IL-1 $\beta$ ) gene are associated with an increased risk of gastric cancer and its precursors. The effects are most likely mediated through the induction of hypochlorhydria and severe corpus gastritis with the subsequent development of gastric atrophy. The roles of IL-1 $\beta$ and other host genetic factors in the pathogenesis of $\mathrm{H}$ pylori related cancer are discussed in this article.

Key Words: Gastric cancer, Helicobacter pylori, Interleukins, Molecular epidemiology, Polymorphisms
T has long been established that human susceptibility to infectious agents is at least partly under genetic control. Several observations from twin, adoptee, pedigree and candidate gene studies point to host genetic factors as key determinants of this susceptibility $(1,2)$. The recent explosion in genetic knowledge, accelerated by the human genome project, is helping to unravel the molecular pathways that mediate genetic susceptibility to human diseases, including infections and cancer (3-5). While genetic susceptibility may apply to the risk of acquiring an infectious agent, it is becoming increasingly recognised that host genes also influence the pathophysiological response to infections, which ultimately determines the clinical outcome.

Infections can cause cancer by a variety of mechanisms, including direct transformation of cells, induction of immunosuppression with consequent reduced cancer immunosurveillance or by causing chronic inflammation. The latter is becoming increasingly recognised as an essential component

\section{Le rôle de l'interleukine-1 béta et d'autres marqueurs génétiques potentiels comme indicateurs de risque de cancer gastrique}

Le Helicobacter pylori infecte la moitié de la population mondiale et s'associe à une gastrite asymptomatique ainsi qu'à des pathologies plus graves, comme l'ulcère peptique et le carcinome gastrique. L'issue clinique dépend en grande partie de la gravité et de la répartition de la gastrite causée par le $\mathrm{H}$ pylori, mais la pathogenèse demeure mal comprise. Des facteurs de virulence bactérienne et des influences environnementales contribuent à la pathogenèse, mais n'expliquent pas les issues divergentes. Selon des données émergentes, des facteurs génétiques de l'hôte jouent un rôle essentiel dans la détermination de l'issue clinique d'une infection à H pylori. En particulier, les génotypes pro-inflammatoires du gène interleukine béta-1 (IL-1B) s'associent à un risque accru de cancer gastrique et de ses précurseurs. Les effets sont plus probablement assistés par l'induction d'hypochlorhydrie et d'une gastrite du corps grave suivies par l'apparition d'une atrophie gastrique. Le rôle de l'IL-1B et d'autres facteurs génétiques de l'hôte dans la pathogenèse du cancer relié au H pylori est abordé dans le présent article. 
probably triggered by the bacterium's lipopolysaccharide, urease and/or cytotoxins, and is mediated by cytokines. Cytokines, including the interleukins, are soluble peptide molecules that mediate the interactions between immunocompetent and haematopoietic cells, and between the immune and neuroendocrine systems (9). They are produced by a variety of activated cells and exert their biological effects by binding to specific receptors on target cells. The cytokine repertoire comprises a multitude of pro- and anti-inflammatory mediators, whose functions are to coordinate an effective immune/inflammatory response against invading pathogens without causing undue damage to the host.

In addition to their pro- or anti-inflammatory properties, some $H$ pylori-induced cytokines have direct effects on gastric epithelial cells, which has a profound effect on gastric physiology. For example, the proinflammatory cytokine interleukin-1 beta $($ IL-1 $\beta$ ) is the most potent of the known agents that are gastric cytoprotective, antiulcer, antisecretory and inhibitors of gastric emptying (10). Wolfe and Nompleggi (11) estimated that on a molar basis, IL-1 $\beta$ is 100 times more potent than both prostaglandins (PGs) and the proton pump inhibitor (PPI) omeprazole, and 6000 times more potent than cimetidine in inhibiting acid secretion. Another important proinflammatory cytokine that is upregulated by $H$ pylori infection is tumor necrosis factor alpha (TNF- $\alpha$ ), which also inhibits gastric acid secretion, but to a lesser extent than IL-1 $\beta$ (12).

In physiological terms, the stomach can be divided into two main compartments: an acidic proximal corpus that contains the acid-producing parietal cells, and a less acidic distal antrum that does not have parietal cells but contains the endocrine cells that control acid secretion (13). H pylori infection is first established in the parts of the stomach that have a higher $\mathrm{pH}$, such as the antrum. This is most likely due to the bacterium's attempt to preserve energy, because although $\mathrm{H}$ pylori is well-equipped for survival at low $\mathrm{pH}$, it is achieved with a high cost of energy expenditure. Thus, high acid production by the parietal cells probably protects the corpus mucosa from initial colonisation. Both animal and human ingestion studies suggest that successful colonisation of the gastric mucosa is best achieved with the aid of acid suppression (14-16). Furthermore, the pharmacological inhibition of acid secretion in infected subjects leads to a redistribution of the infection and its associated gastritis from an antral- to a corpus-predominant pattern (17-19). Thus, the lack of gastric acid extends the area of colonisation and also maximises the tissue damage resulting from this colonisation.

\section{H PYLORI INFECTION AND THE DIVERGENT CLINICAL OUTCOMES}

$H$ pylori infection is associated with divergent clinical outcomes that range from simple asymptomatic gastritis to more serious conditions such as peptic ulcer disease and gastric neoplasia. The extent of this remarkable divergence is made more striking by the observation that certain outcomes of the infection, such as duodenal ulcer disease, are actually protective against others, such as gastric cancer (20). The key determinants of these outcomes are the severity and distribution of the $H$ pylori-induced gastritis. There are three main gastric phenotypes that result from chronic $H$ pylori infection: mild pangastritis, by far the most common phenotype, which does not affect gastric physiology and is not associated with significant human disease; corpus-predominant gastritis associated with gastric atrophy, hypochlorhydria and an increased risk of gastric cancer (21); and antral-predominant gastritis associated with high gastric acid secretion and an increased risk of duodenal ulcer disease (22). The association of $\mathrm{H}$ pylori with such variable outcomes poses a most fascinating scientific challenge, the unravelling of which will not only explain how ulcers and gastric cancer develop, but also will act as a paradigm for gene-environment interactions in most human diseases.

\section{H PYLORI AND GASTRIC CANCER VERSUS DUODENAL ULCER PHENOTYPES}

There is accumulating evidence that the acid secretory capacity of the host is crucial in determining the distribution and natural history of $H$ pylori infection (13). In hosts with low secretory capacity (either genetically determined or secondary to pharmacological inhibition) the bacterium is capable of colonising a wider niche than would otherwise be possible in the presence of high volumes of acid. Colonisation of a wider niche, including the corpus mucosa, leads to corpus gastritis with a resultant functional inhibition of acid secretion. This inhibition is mediated by $\mathrm{H}$ pylori-induced inflammatory cytokines (such as IL-1 $\beta$ and TNF- $\alpha$ ) and the net effect is the establishment of a more aggressive gastritis that accelerates the development of gastric atrophy. Once atrophy develops, acid secretion is attenuated not only by the functional inhibition caused by inflammatory mediators, but also by a more permanent morphological change that is harder to reverse. This situation is very relevant to the subgroup of humans who develop the gastric cancer phenotype in the presence of chronic H pylori infection.

In contrast to subjects who have an increased risk of gastric cancer, subjects who develop duodenal ulcer disease are known to have a large parietal cell mass that is relatively free of $\mathrm{H}$ pylori-induced inflammatory activity. This pattern of antralpredominant gastritis with high acid output characterizes the duodenal ulcer diathesis. The high acid output is associated with the development of duodenal gastric metaplasia, a mechanism that protects against the persistent delivery of an increased acid load to the duodenum. The presence of gastric epithelium in the duodenum is an invitation for antral $H$ pylori infection to colonise this new niche. The ensuing gastritis, and its accompanied production of proinflammatory cytokines such as IL-1 $\beta$ and TNF- $\alpha$, greatly weakens the resistance of this mucosa, and in the presence of large volumes of acid and a reduction in duodenal mucosal bicarbonate production (23), ulcers develop.

As mentioned above, the effect of acid secretion on changing the distribution of $H$ pylori colonisation and gastritis is most markedly exposed in subjects in whom acid secretion is manipulated by pharmacological means. Thus, $H$ pylori-infected subjects on long term PPIs undergo a shift from antralpredominant gastritis to corpus-predominant and have a higher risk of developing gastric atrophy, a precursor lesion for gastric neoplasia (18). This observation provided a clue for the potential role of endogenous substances that could also inhibit acid secretion, such as IL-1 $\beta$ and TNF- $\alpha$. As will be discussed, these two cytokines were prime candidates as host genetic factors that may increase the risk of gastric cancer. IL-1 $\beta$ is the archetypal pleiotropic cytokine, produced by many cells and exerting its biological effects on almost all cell types (24). IL-1 $\beta$ is a very potent proinflammatory cytokine and is involved in the host's response to many antigenic challenges. 


\section{COPYRIGHT PULSUS G OU GENETIC POLYMORPHISMS IN THE IL-1 GENE CLUSTER INCREASE THE RISK OF GASTRIC CANCER AND ITS PRECURSORS}

A large volume of research has focussed on the role of bacterial virulence factors in the pathogenesis of gastroduodenal diseases. Although these factors undoubtedly contribute to the degree of tissue damage, they do not distinguish between the two key outcomes; namely, duodenal ulcers and gastric cancer (25). This prompted us to concentrate on the host genetic factors that may be relevant to this process. The search for the appropriate candidate genes had to stem from a profound understanding of gastric physiology and the way it is disrupted by $\mathrm{H}$ pylori infection. Because $\mathrm{H}$ pylori achieves most of its damage through the induction of chronic inflammation, it was reasonable to consider genes that control this process as appropriate candidates.

The IL-1 gene cluster on chromosome $2 \mathrm{q}$ contains three related genes within a $430 \mathrm{~kb}$ region, IL-1A, IL-1B and IL-1RN, which encode for the pro-inflammatory cytokines IL-1 $\alpha$ and IL-1 $\beta$, as well as their endogenous receptor antagonist IL-1ra, respectively (24). IL-1 $\beta$ is upregulated in the presence of $\mathrm{H}$ pylori and plays a central role in initiating and amplifying the inflammatory response to this infection $(26-30)$. IL-1 $\beta$ is also an extremely potent inhibitor of gastric acid secretion $(10,11,31)$. Three diallelic polymorphisms in IL-1B have been reported, all representing cytosine (C)-thymine (T) or T-C transitions, at positions $-511,-31$, and +3954 bp from the transcriptional start site (32). There are conflicting data regarding the functional effects of these polymorphisms on IL-1 $\beta$ production $(33-35)$. The IL-IRN gene has a penta-allelic 86 bp tandem repeat (variable number of tandem repeats) in intron 2; the less common allele 2 (IL$\left.1 R N^{*} 2\right)$ is associated with a wide range of chronic inflammatory and autoimmune conditions (32). IL-1RN*2 is associated with enhanced IL-1 $\beta$ production in vitro (33), but data regarding its effects on IL-1ra production are contradictory (36-40). The presence of such highly prevalent and functional genetic polymorphisms provided an ideal opportunity to design the appropriate epidemiological studies to test for the role of these candidate loci.

We first studied the correlation of these high IL-1 $\beta$ genotypes (two polymorphisms in the IL-1B and IL-1RN genes) with hypochlorhydria and gastric atrophy in a white population of gastric cancer relatives from Scotland. These relatives were known to have an increased risk of developing the same cancer and had a higher prevalence of the precancerous abnormalities, but only in the presence of $\mathrm{H}$ pylori infection. We found that the high IL- $1 \beta$ genetic markers significantly increased the risk of these precancerous conditions. In a logistic regression model including both genotypes, the estimated age-adjusted odds ratios for IL-1B $-511 /-31 * 2+$ and IL-1RN*2/*2 were 7.5 (95\% CI 1.8 to 31$)$ and $2.1 \%(95 \%$ CI 0.7 to 6.3 ), respectively (41). We proceeded to examine the association between the same IL-1 $\beta$ genetic polymorphisms as in the Scotland population and gastric cancer using another case-control study, which included 366 white gastric cancer patients and 429 white population controls from Poland. We confirmed the same positive association between these genotypes and gastric cancer. In a logistic regression model including both genotypes, the estimated odds ratios for IL $-1 \beta-511 /-31 * 2+$ and IL-1RN*2/*2 were 1.6 (95\% CI 1.2 to 2.2 ) and 2.9 (95\% CI 1.9 to 4.4 ), respectively (41).

\section{PINC, = DO NOT COPY}

We have since confirmed our initial observations with another white case-control study from the United States, consisting of 188 gastric cancer cases and 210 controls (42). In this study, the proinflammatory IL-1 genotypes (IL-1B-511 and IL-1RN) conferred similar odds ratios for noncardia gastric adenocarcinoma as in the Polish study. In yet another white population from Portugal, Machado et al (43) independently confirmed our findings in relation to the IL-1 gene cluster markers, reporting similar odds ratios. Finally, Furuta et al (44) have recently shown that Japanese subjects with the proinflammatory IL-1B-511 genotypes had the highest atrophy and gastritis scores, the highest median gastric juice $\mathrm{pH}$ and the lowest median serum PG I/PG II ratios, but only in $H$ pylori-infected subjects. This independent confirmation, which includes different ethnic groups, strengthens confidence in the role IL- $1 \beta$ plays in this human disease.

Although $I L-1 \beta$ was the perfect candidate gene, other genes involved in the $H$ pylori-induced gastritis cascade are also legitimate targets. Our most recent search has confirmed positive but weaker roles for functional polymorphisms in the TNF-A and IL-10 genes (42). The TNF- $\alpha$ polymorphism increases the risk of gastric cancer and its precursors in a similar fashion to the IL-1 $\beta$ polymorphisms. This proinflammatory cytokine is also upregulated in $H$ pylori infection and has acid inhibitory properties, albeit weaker ones than IL1- $\beta$. IL-10 is an anti-inflammatory cytokine that downregulates key proinflammatory cytokines such as IL-1 $\beta$, TNF- $\alpha$ and Interferon-gamma. Polymorphisms that correlate with low IL-10 levels increase the risk of gastric cancer. Indeed, the risk of gastric cancer rises sharply in subjects who have a composite collection of proinflammatory markers. We found that the odds ratio increased to 27 in subjects with three or four proinflammatory genotypes (42). There is no doubt that other genetic markers will be uncovered that have a direct effect on the host's response to $H$ pylori infection. Work is ongoing to try to identify more of these host genetic factors.

But how do these IL-1 $\beta /$ TNF- $\alpha /$ IL-10 polymorphisms explain the divergent outcomes of $H$ pylori infection? We speculate that the effect of these polymorphisms operates early in the disease process and requires the presence of $H$ pylori infection. When $H$ pylori infection challenges the gastric mucosa, a vigorous inflammatory response with high IL-1 $\beta /$ TNF- $\alpha$ and low IL-10 may appear to be beneficial, but has the unfortunate effect of switching acid secretion off, thus, allowing the infection to extend its colonisation and damaging inflammation to the corpus mucosa, an area that is usually well protected by acid secretions. A decreased flow of acid will also undermine attempts to flush out these toxic substances, causing further damage to the mucosa. More inflammation in the corpus leads to more inhibition of acid secretion and a continuing cycle that accelerates glandular loss and the onset of gastric atrophy. It is apparent that this vicious cycle ultimately succeeds in driving the infection out, but at a very high price for the host. This is amply demonstrated by the finding that $H$ pylori density becomes progressively lower with the progression from mild gastritis through severe gastritis, atrophy and intestinal metaplasia. Indeed, by the time gastric cancer develops, it is extremely hard to demonstrate any evidence of the infection (45). 


\section{ROLE OF ENVIRONMENTAL FACTORS IN GASTRIC CARCINOGENESIS}

But why do only a few $H$ pylori-infected subjects with these polymorphisms develop gastric cancer? Why isn't everyone with such a genetic makeup at risk of this outcome? The answer lies in the polygenic and multifactorial nature of most complex human diseases. These genetic factors operate only in the presence of an infectious agent and lead to the development of an atrophic phenotype. The progression of atrophy towards cancer depends on other components of the host genetic constitution acting epistatically, as well as on dietary and other factors in the environment. For example, it is known that men are twice as likely as women to develop distal gastric adenocarcinoma. The sex difference raises the interesting possibility that either hormonal factors, such as estrogens, or perhaps the lower body content of iron in females, which is carcinogenic in other tissues such as the liver, may explain the difference in risk. Furthermore, while $H$ pylori infection and the host's genetics interact to initiate a hypochlorhydric and atrophic phenotype, environmental cofactors may mediate subsequent neoplastic transformation even after the disappearance of the infection. Diet may be particularly relevant: a greater consumption of fresh fruits and vegetables has been shown to protect against risk of gastric as well as several other cancers. Dietary vitamin C reduces the formation of $\mathrm{N}$-nitroso compounds and scavenges mutagenic reactive oxygen metabolites generated by gastric inflammation (46), and supplemental vitamin C is associated with a significantly lower risk of noncardia gastric cancer (47). Furthermore, vitamin $\mathrm{C}$ concentrations and bioavailability are reduced in the presence of $H$ pylori infection $(48,49)$. Another important cofactor is cigarette smoking, which was found to

\section{REFERENCES:}

1. Hill AV. The genomics and genetics of human infectious disease susceptibility. Annu Rev Genomics Hum Genet 2001;2:373-400.

2. Hill AV. The immunogenetics of human infectious diseases. Annu Rev Immunol 1998; 16:593-617.

3. Subramanian G, Adams MD, Venter JC, Broder S. Implications of the human genome for understanding human biology and medicine. JAMA 2001;286:2296-307.

4. Subramanian G, Mural R, Hoffman SL, Venter JC, Broder S. Microbial disease in humans: A genomic perspective. Mol Diagn 2001;6:243-52.

5. Ponder BA. Cancer genetics. Nature 2001;411:336-41.

6. Kuper H, Adami HO, Trichopoulos D. Infections as a major preventable cause of human cancer. J Intern Med 2000;248:171-83.

7. Parsonnet J. Introduction. In: Parsonnet J, ed. Microbes and Malignancy. New York: Oxford University Press, 1999:3-15.

8. Israel DA, Peek RM. Pathogenesis of Helicobacter pylori-induced gastric inflammation. Aliment Pharmacol Ther 2001;15:1271-90.

9. Fridman WH, Tartour E. Cytokines and cell regulation. Mol Aspects Med 1997;18:3-90.

10. Robert A, Olafsson AS, Lancaster C, Zhang WR. Interleukin-1 is cytoprotective, antisecretory, stimulates PGE2 synthesis by the stomach, and retards gastric emptying. Life Sci 1991;48:123-34.

11) Wolfe MM, Nompleggi DJ. Cytokine inhibition of gastric acid secretion - A little goes a long way. Gastroenterology 1992;102:2177-8.

12. Beales IL, Calam J. Interleukin 1 beta and tumour necrosis factor alpha inhibit acid secretion in cultured rabbit parietal cells by multiple pathways. Gut 1998;42:227-34.

13. McColl KE, El-Omar E, Gillen D. Helicobacter pylori gastritis and gastric physiology. Gastroenterol Clin North Am 2000;29:687-703.

14. Marshall BJ, Armstrong JA, McGechie DB, Glancy RJ. Attempt to fulfil Koch's postulates for pyloric Campylobacter. Med J Aust 1985;142:436-9.

15. Morris A, Nicholson G. Ingestion of Campylobacter pyloridis causes gastritis and raised fasting gastric $\mathrm{pH}$. Am J Gastroenterol 1987;82:192-9. nearly double the risk of transition from atrophic gastritis to dysplasia in a high risk population (50). Thus, cytokine gene polymorphisms represent only one component of the complex interplay among host, pathogen and environmental factors involved in gastric carcinogenesis.

These proinflammatory polymorphisms, therefore, can distinguish between subjects who will develop the hypochlorhydric atrophic phenotype in response to $\mathrm{H}$ pylori infection and those who will manage to limit the infection to a smaller area and offer relatively better protection of their corpus function.

\section{CONCLUSIONS}

IL-1 $\beta$ is a very important proinflammatory cytokine with profound effects on gastric physiology. Its acid inhibitory properties uniquely qualify it as a major player in the host's response to $H$ pylori infection and the diseases associated with it. Polymorphisms in the gene for IL- $1 \beta$ that correlate with higher levels of this cytokine have been found to increase the risks of hypochlorhydria and gastric atrophy in response to $\mathrm{H}$ pylori infection and to increase the risk of gastric cancer itself. These host genetic factors that affect IL-1 $\beta$ may determine why some individuals infected with $H$ pylori develop gastric cancer while others do not. Future research should focus on identifying the molecular pathways that mediate this increased risk. The search for other host genetic factors that contribute to the pathogenesis of the disease should continue, particularly in view of the ever-expanding opportunities made possible by the human genome project. A special effort should be directed at understanding these host genetic factors in populations with high and low incidences of gastric cancer.

16. Danon SJ, O'Rourke JL, Moss ND, Lee A. The importance of local acid production in the distribution of Helicobacter felis in the mouse stomach. Gastroenterology 1995;108:1386-95.

17. Kuipers EJ, Uyterlinde AM, Pena AS, et al. Increase of Helicobacter pylori-associated corpus gastritis during acid suppressive therapy: implications for long-term safety. Am J Gastroenterol 1995;90:1401-6.

18. Kuipers EJ, Lundell L, Klinkenberg-Knol EC, et al. Atrophic gastritis and Helicobacter pylori infection in patients with reflux esophagitis treated with omeprazole or fundoplication. N Engl J Med 1996;334:1018-22.

19. Kuipers EJ, Lee A, Klinkenberg-Knol EC, Meuwissen SG. Review article: The development of atrophic gastritis- Helicobacter pylori and the effects of acid suppressive therapy. Aliment Pharmacol Ther 1995;9:331-40.

20. Hansson LE, Nyren O, Hsing AW et al. The risk of stomach cancer in patients with gastric or duodenal ulcer disease. N Engl J Med 1996;335:242-9.

21. El-Omar EM, Oien K, El Nujumi A, et al. Helicobacter pylori infection and chronic gastric acid hyposecretion. Gastroenterology 1997;113:15-24.

22. El-Omar EM, Penman ID, Ardill JE, et al. Helicobacter pylori infection and abnormalities of acid secretion in patients with duodenal ulcer disease. Gastroenterology 1995;109:681-91.

23. Hogan DL, Rapier RC, Dreilinger A, et al. Duodenal bicarbonate secretion: Eradication of Helicobacter pylori and duodenal structure and function in humans. Gastroenterology 1996;110:705-16.

24. Dinarello CA. Biologic basis for interleukin-1 in disease. Blood 1996;87:2095-147.

25. Graham DY, Yamaoka Y. Disease-specific Helicobacter pylori virulence factors: The unfulfilled promise. Helicobacter 2000;5 (Suppl 1):S3-S9.

26. Noach LA, Bosma NB, Jansen J, et al. Mucosal tumor necrosis factor-alpha, interleukin-1 beta, and interleukin-8 production in patients with Helicobacter pylori infection. Scand J Gastroenterol 1994;29:425-9.

27. Basso D, Scrigner M, Toma A, et al. Helicobacter pylori infection 
enhances mucosal interleukin-1 beta, interleukin-6, and the soluble receptor of interleukin-2. Int J Clin Lab Res 1996;26:207-10.

28. Jung HC, Kim JM, Song IS, Kim CY. Helicobacter pylori induces an array of proinflammatory cytokines in human gastric epithelial cells: quantification of mRNA for interleukin-8, -1 alpha/beta, granulocyte-macrophage colony-stimulating factor, monocyte chemoattractant protein-1 and tumour necrosis factor-alpha. J Gastroenterol Hepatol 1997;12:473-80.

29. Wilkinson RJ, Patel P, Llewelyn M, et al. Influence of polymorphism in the genes for the interleukin (IL)-1 receptor antagonist and IL-1beta on tuberculosis. J Exp Med 1999;189:1863-74.

30. Sciacca FL, Ferri C, Vandenbroeck K, et al. Relevance of interleukin 1 receptor antagonist intron 2 polymorphism in Italian MS patients. Neurology 1999;52:1896-8.

31. Engebretson SP, Lamster IB, Herrera-Abreu M, et al. The influence of interleukin gene polymorphism on expression of interleukin-1beta and tumor necrosis factor-alpha in periodontal tissue and gingival crevicular fluid. J Periodontol 1999;70:567-73.

32. Bidwell J, Keen L, Gallagher G, et al. Cytokine gene polymorphism in human disease: On-line databases. Genes Immun 2001;2(Suppl 1):S61-S70.

33. Hurme M, Santtila S. IL-1 receptor antagonist (IL-1Ra) plasma levels are co-ordinately regulated by both IL-1ra and IL-1beta genes. Eur J Immunol 1998;28:2598-602.

34. Pociot F, Molvig J, Wogensen L, Worsaae H, Nerup J. A TaqI polymorphism in the human interleukin-1 beta (IL-1 $\beta$ ) gene correlates with IL-1 $\beta$ secretion in vitro. Eur J Clin Invest 1992;22:396-402.

35. Donn RP, Farhan AJ, Barrett JH, et al. Absence of association between interleukin 1 alpha and oligoarticular juvenile chronic arthritis in UK patients. Rheumatology (Oxford) 1999;38:171-5.

36. Danis VA, Millington M, Hyland VJ, Grennan D. Cytokine production by normal human monocytes: inter-subject variation and relationship to an IL-1 receptor antagonist (IL-1Ra) gene polymorphism. Clin Exp Immunol 1995;99:303-10.

37) Tountas NA, Casini-Raggi V, Yang H, et al. Functional and ethnic association of allele 2 of the interleukin- 1 receptor antagonist gene in ulcerative colitis. Gastroenterology 1999;117:806-13.

38. Andus T, Daig R, Vogl D, et al. Imbalance of the interleukin 1 system in colonic mucosa-association with intestinal inflammation and interleukin 1 receptor antagonist [corrected] genotype 2. Gut 1997;41:651-7.
39. Cork MI, Crane AM, Duff GW. Genetic control of cytokines. Cytokine gene polymorphisms in alopecia areata. Dermatol Clin 1996;14:671-8

40. Perrier S, Coussediere C, Dubost JJ, Albuisson E, Sauvezie B. IL-1 receptor antagonist (IL-1RA) gene polymorphism in Sjogren's syndrome and rheumatoid arthritis. Clin Immunol Immunopathol 1998;87:309-13.

41. El-Omar EM, Carrington M, Chow WH, et al. Interleukin-1 polymorphisms associated with increased risk of gastric cancer. Nature 2000;404:398-402.

42. El-Omar EM, Chow WH, Gammon MD, Vaughan TL, Risch HA Fraumeni JF Jr. Pro-inflammatory genotypes of IL- $1 \beta$; TNF- $\alpha$ and IL-10 increase risk of distal gastric cancer but not of cardia or oesophageal adenocarcinoma. Gastroenterology 2001;120(Suppl 1): A86. (Abst A86)

43. Machado JC, Pharoah P, Sousa S, et al. Interleukin $1 \beta$ and interleukin $1 \mathrm{RN}$ polymorphisms are associated with increased risk of gastric carcinoma. Gastroenterology 2001;121:823-9.

44. Furuta T, El Omar EM, Xiao F, et al. Interleukin 1beta polymorphisms increase risk of hypochlorhydria and atrophic gastritis and reduce risk of duodenal ulcer recurrence in Japan. Gastroenterology 2002;123:92-105.

45. Kuipers EJ. Review article: Exploring the link between Helicobacter pylori and gastric cancer. Aliment Pharmacol Ther 1999;13(Suppl 1):3-11.

46. Correa P. Human gastric carcinogenesis: A multistep and multifactorial process- First American Cancer Society Award Lecture on Cancer Epidemiology and Prevention. Cancer Res 1992;52:6735-40.

47. Mayne ST, Risch HA, Dubrow R, et al. Nutrient intake and risk of subtypes of esophageal and gastric cancer. Cancer Epidemiol Biomarkers Prev 2001;10:1055-62.

48. Banerjee S, Hawksby C, Miller S, et al. Effect of Helicobacter pylori and its eradication on gastric juice ascorbic acid. Gut 1994;35:317-22.

49. Woodward M, Tunstall-Pedoe H, McColl K. Helicobacter pylori infection reduces systemic availability of dietary vitamin $\mathrm{C}$. Eur J Gastroenterol Hepatol 2001;13:233-7.

50. Kneller RW, You WC, Chang YS, et al. Cigarette smoking and other risk factors for progression of precancerous stomach lesions. J Natl Cancer Inst 1992;84:1261-6. 


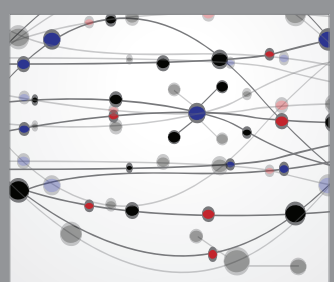

The Scientific World Journal
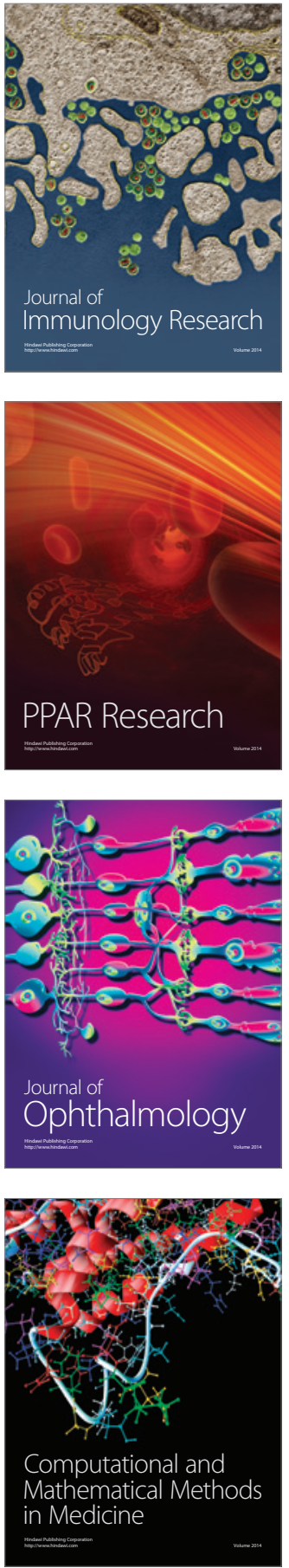

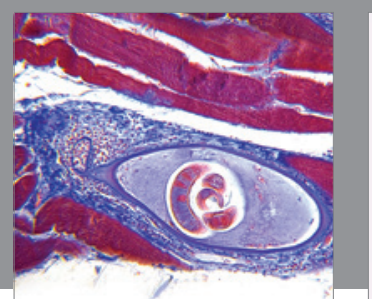

Gastroenterology Research and Practice

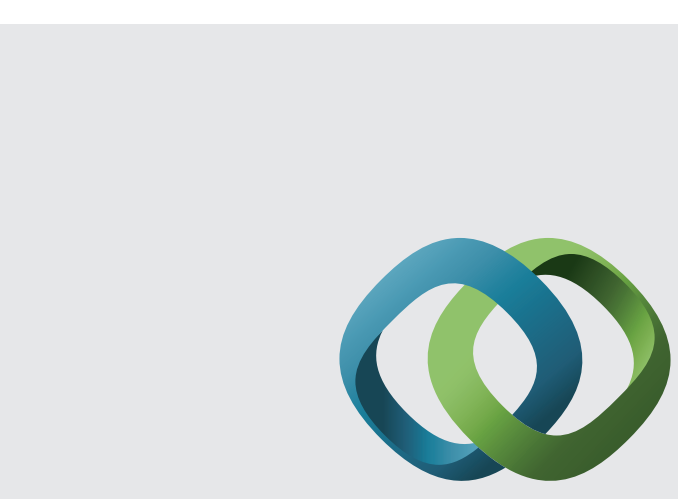

\section{Hindawi}

Submit your manuscripts at

http://www.hindawi.com
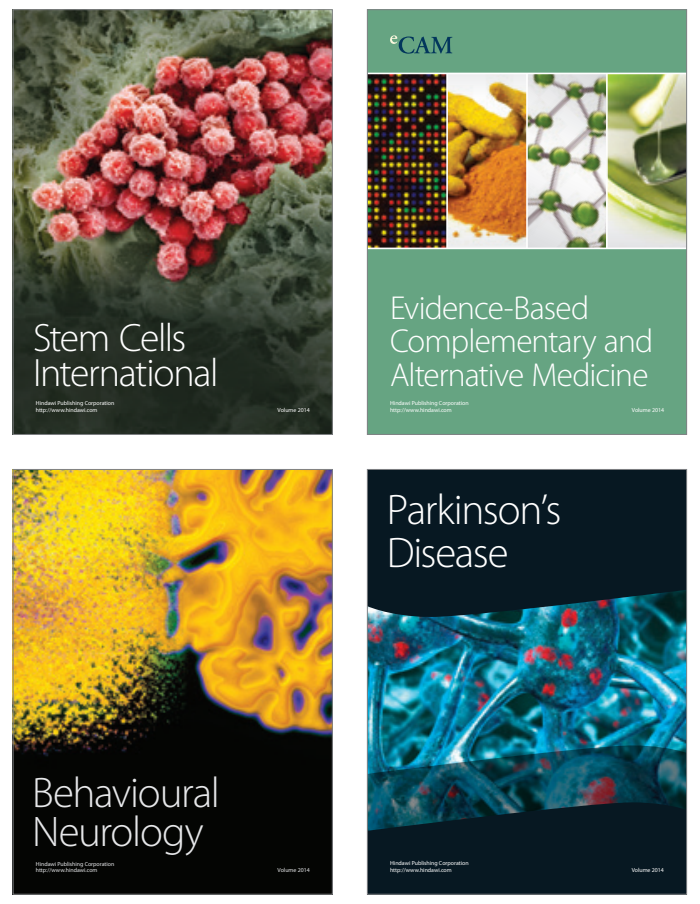
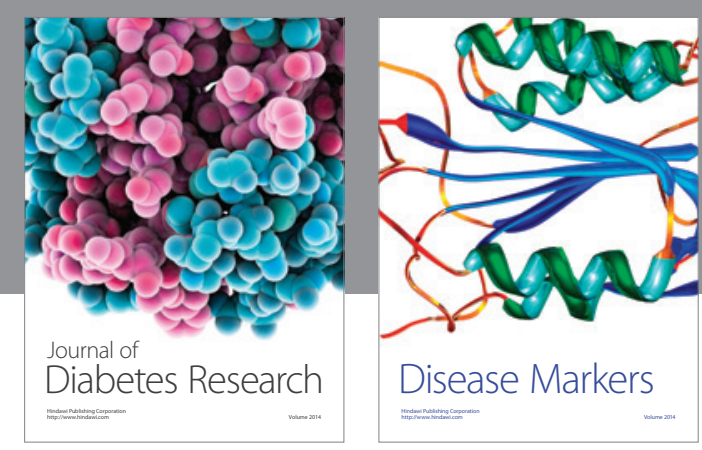

Disease Markers
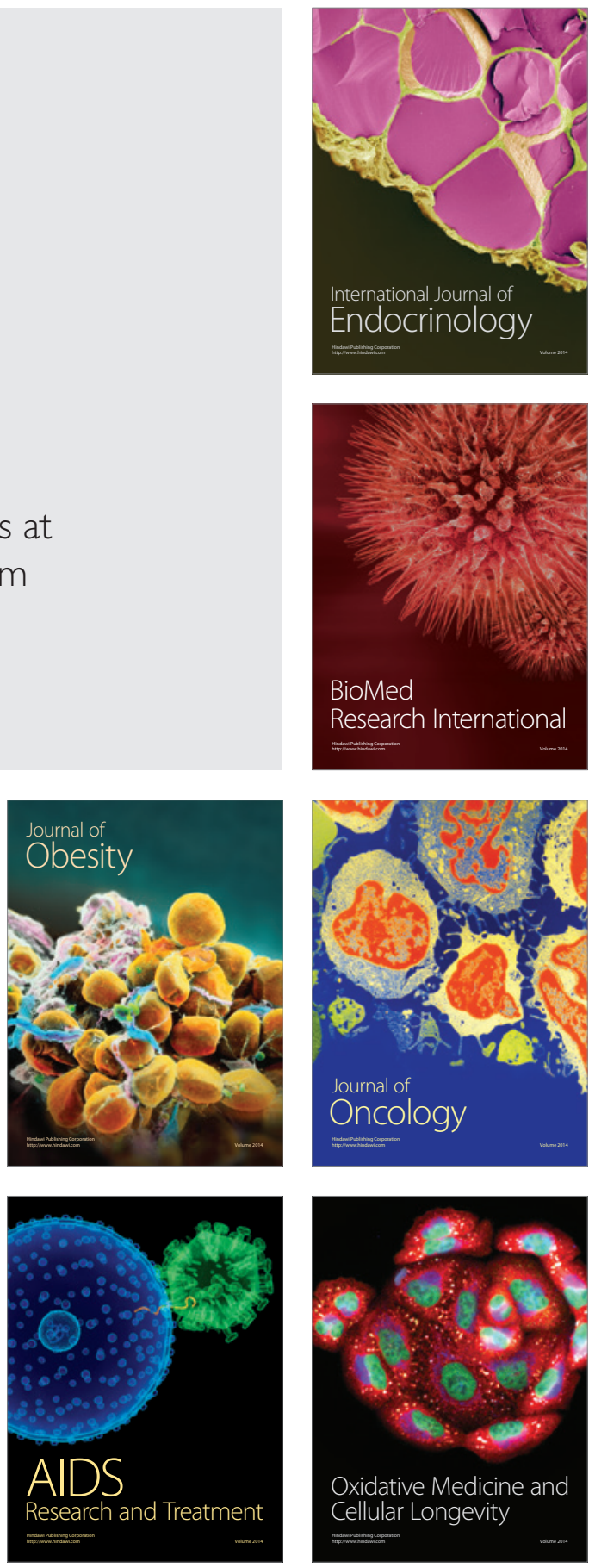